\title{
Emotional Connect between Brand and Consumer through Sensory Branding
}

\author{
Makarand Upadhyaya \\ Department of Management and Marketing, College of Business Administration, University of Bahrain, Sikhar, Bahrain \\ Email: makarandjaipur@gmail.com
}

How to cite this paper: Upadhyaya, M. (2017) Emotional Connect between Brand and Consumer through Sensory Branding. American Journal of Industrial and Business Management, 7, 352-359. https://doi.org/10.4236/ajibm.2017.74025

Received: December 7, 2016

Accepted: April 3, 2017

Published: April 6, 2017

Copyright $\odot 2017$ by author and Scientific Research Publishing Inc. This work is licensed under the Creative Commons Attribution International License (CC BY 4.0).

http://creativecommons.org/licenses/by/4.0/ (c) (i) Open Access

\begin{abstract}
Branding is a key factor in marketing. In the past, most of the companies were using audio-visual stimuli for differentiating their brands from the competitors. Now companies are working hard to achieve some degree of differentiation in their brands from the competitors by using all five senses (taste, smell, sight, touch and sound). This phenomenon is called sensory branding, which helps the company to differentiate their brand's products from the competitors. The aim of sensory branding is to use all the five senses at the same time to create a five-dimensional experience for the consumer. In a cluttered market where even advertising fails to create a brand sensory branding appears to be subtle, pleasant and insidious way of creating a compelling brand experience.
\end{abstract}

\section{Keywords}

Consumers, Sensory Branding, Brand Awareness, Five Senses, Brand Identity

\section{Introduction}

In today's world, a lot of brands are being inducted in the product category in the markets than ever before. It has caused the product category to be completely cluttered. It becomes hard for the customer to recall all the brands for a single product as the number for brands in the same product category is growing immensely and is causing confusion and chaos between humans. It's time to move out of the traditional marketing methods and do something creative and innovative which is very basic and also leaves a mark on consumers' everyday lives.

It's important for the brand to make a place in the consumers' minds and that's what the corporates today need to learn. If the brand is not able to perform in its distinctive benefits, no amount of dressing can do any good for the brand. The functionary, emotional and sensory expenses is a complete package that the brand should provide and they need to be geared up for this. A compelling 
brand experience is made by touching and triggering all the five senses of the consumers mind like touch, smell, sight, sound and taste. To make the bonding between the brand and a consumer reach higher levels, it's important for the brand to have multi-sensory appeals as the more multi-sensory appeal the brand has the higher is the number of sensory memories activated and as a result the bonding gets stronger.

To promote an everlasting touching tie linking the brand and the consumer sensory branding is used by using a purposeful plan and operation of interface between the senses. The values, feelings, emotions that we have are stored in our memory banks. To tap right into our emotions, senses are helpful as they are linked to our memory and can tap right into our emotions. All these five senses are used to create an impact on the consumer. Most advertising campaigns mainly aim only two senses of sight and sound and the three specially smell largely ignored. Our sense of smell is actually very important as it generates $75 \%$ of our emotions as indicated by the brand sense research. This is an anomaly that the current day communication needs to address.

In today's business environment, it is too much competition. The market is swamped with new brands and intensity of brand war is increasing day by day. So, identity of a brand became the vital issue for the company. Now companies are working hard to achieve some degree of differentiation in their brands from the competitors. As Lindstrom [1] say that many companies have sought to achieve this differentiation of their products through sensory branding or five senses (taste, smell, sight, sound and touch). Recently the involvement of the five senses-sound, sight, smell, touch and taste-in branding have become popular. Previously, most of the companies were using two senses (sight \& sound), but now they are trying to use five senses to distinguish them from the competitors. This phenomenon is called sensory branding stated by Bhimrao [2], which helps the company to differentiate their brand's products from the competitors. Sensory branding allows the company to use of new communication channels. By using two dimensional perspective of branding, which includes audiovisual stimulus is not enough for differentiate a brand to the customer in the present situation.

\section{The Senses and Sensory Elements}

Sight-Sight often overrules all other senses by being it the most seductive of all other senses.

Sound-As it is not attached to mood and only $4 \%$ of the fortune 500 brands employtone online.

Touch-In sensory branding skin being the major of all sensory organs is widely used a sensation in sensory branding. Skin is an important element which enables the sense of touch.

Taste-The sense of taste is highly effective but is hard to introduce.

Smell-Smell is 10,000 times more receptive then taste and also has an overriding influence over it. 
Color, name, iconography, navigation, behaviour, tradition, shape, language, ritual, sound, service, picture are the sensory elements involved in creating a successful sensory brand.

\section{Advantages of Sensory Branding}

Sensory branding helps to pre-empt brand commoditization by breaking through the clutter Djurovic [3]. The desired end game results include achieving marketing objectives by encouraging trail, increasing brand usage and creating a meaningful and last point-of-difference over competition using sensory branding enabled experience objectives.

Sensory branding helps to achieve the following objectives

- Create or evoke memories.

- Establish brand associations.

- Establish emotional bonds.

- Create pleasant sensations.

- Amplify the brand familiarity.

- Generate a hum and interest in sharing experiences with others.

- Affect the perception of quality of the product and thus the value of the brand.

Martin Lindstorm [4] in his study reveals a co-relation between the number of senses the brand appeals to and its price. The term Trade Dress was introduced by him. How a brand sounds, feel, taste, shape and smell combine and makes it Trade Dress. The more senses the brand can appeal to the more it's better for the brand because of the pleasant, insidious, and sub tile nature of sensory branding in attracting customers without them even being aware of it.

\section{Sensory Brand in Action}

In service industry where the combination of goods and service to create an experience is deployed for sensory branding by Keller [5]. Most of the examples below are from the service industry but this concept can also be applied by the fast moving consumer goods (FMCG) at the terminus of the entire supply chain network which is the retailer.

\subsection{Automobile Industry}

Automobile industry pioneered sensory branding. As pointed out by Krishna [6] Sound and Smell were the two senses used by the industry vehemently to make an impact on the perspective buyers, so that every touch point is planned strategically. By the late 1990s, GE and Daimler Chrysler had departments that researched on what kind of sound that the car door will make when the potential buyer slams it hard. The sound of the door slamming gives a perspective about the strength and durability of the solid engineering of the car. The sound statement that the perspective looks for is created by a well-designed team which consists of sound engineers, engineers, product designers and physiologists and is very characteristic for the brand it is created for. The sound enhances the val- 
ues for example, strudness, safety and trust that are a base for any brand. Thus an entire concept of a car is made based on form, touch and sound viewpoint. Smell is not something that is not left to accident. Rolls Royce has recognised a long relation that the sense of smell forms between the car and its owner.

\subsection{Telecom Industry}

Signature tunes have been designed by many telecom companies to help their customers to connect with them in a better way and stay updated with the latest offerings. For example Airtel shared a long bonding with the Oscar winning musician A. R. Rehman who composed a signature tune for the brand and which became the signature tune for the brand. The tune became the most wanted tune and was downloaded by 60 million people. When Rehman composed the tune Airtel had 3 million customers. The company said in a statement that today Airtel has over 90 million customers. Rehman became the Airtel brand ambassador in 3003 and even created a sound track for Airtel Delhi half marathon in 3008 .

Similarly Reliance Industries gives their credit to Shankar, Ehsaan and Loy who created the signature tune for them.

Brand recognition and memorability is created by activities like A. R. Rehman creating a signature tune for Airtel or reliance hiering Shankar Ehsaan Loy to make the signature tune. But the success lies in the exposure to this over a long period of time.

\subsection{Kellogg's}

Crunchiness means Kellogg's. Even if the taste remains perfect the crunchiness that Kellogg's possesses should be stable, if not Kellogg's is not considered fit for consumption. The success of the product totally depends on the sound of the crunch that we hear when we consume the product. The crunch that we hear when we take the first bite, this crunch sound is very important than any other sounds hear able in the commercial.

To decipher the relation between taste and crunch Kellogg's have initiated laboratory experiments. A Danish Commercial Laboratory was hired for Kellogg's due to its speciality in precisecrispy sensation of a breakfast cornflakes. The agency which was hired created an extremely unique crunch sound for Kellogg's. So it's not astonishing to say that Kellogg's is marketing the crunchiness to an extent that the company wants a patient for the same crunchiness sound.

To distinguish the product from other competitors, the crunch sound has very little to do with the quality of the product but it has a lot to do with the relationship of the product.

\subsection{COCO-Cola}

COCO-Cola can be said as an example of tactical branding. The shape of the bottle is designed to be recognized by everyone from larger distances and it can be recognizable even in the dark. To fight substitutions we need a new packaging 
"a new bottle". We need a coco-cola bottle which a person recognises it even when holding in the dark. The coco-cola bottle is designed in a manner that even if the bottle broke down a person can still easily recognize what brand the bottle belongs to. A Design which could be protected by trademark and patient law was suggested to the company's legal counsel in 1915. In response the Root Glass Company in Indiana developed a contour glass coke bottle. The masses nicknamed the bottle as Hobble's Skirt, but the company had named it contoured bottle. A hot fad in those days was the Hobble Skirt and long skirt tied together. The bottle which was designed received so much commercial success due to its unique and essential design, the success was so big that it received a place in the Museum of Contemporary Art in New York. The US Patient office gave the Trademark status as it was one of the rarest packaging.

\subsection{Airline}

\section{Singapore Airlines}

To boost their corporate identity the Singapore airlines in 1990 commissioned aroma-Stefan Floridian waters. At Singapore airlines the aroma become the one and only element in Branding. Comforting the olfactory senses of the passengers a new set of brand tool developed by the airlines in the AROMA. The aroma which is specially designed for the Singapore airlines have induced the aroma in everything related to Singapore airlines, starting from the airhostess perfume, the aroma of the newspapers, the aroma inside the aircraft, the hot towels given to passengers just before the flight takes off this aroma is permitted to the entire servicescape. This Aroma was then formed into a travelling experience offered to passengers and became a distinctive trademark of Singapore Airlines. It gave a warm comfortable memory as soon as passengers entered the plane. Achieving a true sensory synergy is what success lies in. A distinctive odour for other brands should also be there to create an even stronger and long lasting impact on the customers.

\subsection{Retail}

- Ingredients used in sensory branding can be the ambience of the store, the music, the lightning, and the smell. A special smell can be observed in the ladies section of Shoppers Stop or W so that the women get influenced with the smell and thus spend more time and money on the outlet.

- Shelf Spacing - this involves a positioning of the right product on the right self so that it can be seen from the eye level of the customer.

- Packaging - to give a special feel to the product packaging is an integrated part.

\subsection{Starbucks Coffee}

Starbucks in restoring the sensory branding ways to increase store revenue and generate profits. One of the changes is that the store has started to grind the coffee at its own stores to increase the aroma of the coffee. It is cheaper to ship the 
coffee at pre ground stages but the management of starbucks thinks that any productivity loss at the store will lead to customer loyalty and increase in sales. Across the globe the aroma of Starbucks coffee is identifiable.

Earlier by selling the egg sandwich breakfast starbucks admitted that they had committed sensory blunder. It was a sensory mistake because the aroma of the egg sandwich conflicted with the aroma of the coffee. The starbucks employees are strictly instructed not to wear any perfumes, deodorants or smoke, because the smell from these materials can mix with the aroma of starbucks thus tampering the customer experience.

\subsection{Intel Bong}

The most recognised signature music id in the world in Intel Bong. On $11^{\text {th }}$ may 3009 Intel bong marked the beginning of an intense marketing campaign. "Sponsors of Tomorrow" is the name of the campaign in which it's like promoting an entire company and not just the product. NASDAQS traditional bell has been replaced by another familiar sound by Intel bong which has happened for the first time ever. The main aim of the campaign is to promote the Intel Company as "move society forwards by Quantum Leaps Company" rather than its very old microchip processers explained by Upshawm [7]. The bong is a sound mark which gives instant recognition to the company

\section{Suggestions for Creating a Retail Sensory Brand}

Sensory messages are suggested to be patented.

- What customer Sees-By standardizing the ambience it's important to observe what the customer sees in the ambience. Winter [8] states that customer observations can depend on anything starting from the color of the light, the intensity of the light and the number of lights per square feet. The color of the brand should be inflicted on the uniform of the crew if any, for example the crew members of kingfisher airlines wore uniforms of the same color as of the brand.

- What Customers hear-The music which will play in the store should be selected very carefully based on the brand value and essence. For an Ethnic brand a mild instrumental music will fir, but for a trendy brand or a new age brand a techno brand would suit its essence. The sound level and time table should be consistent when it comes to multi site outlets.

- What the customer Smells-As stated by Vlahos [9] that smell of the brand that the customer smells should remain the same all over the globe. The smell should be used in all aspects of the brand starting from its packaging, the tissues, the aroma of the ambience etc. In North Europe the supermarkets are connected with pipelines. These pipelines originate from a bakery store which throw its unique aroma in the supermarket thus making the customers hungry, with the result more and more customers rush to the bakery to satisfy their hunger and this is how the strategy works.

- What Customers taste-the taste is very important for the brand to grow if 
one belongs to the food industry. There are more then 1000 ways to make the brand stay in the mind of the customer through brand placement, in-program sponsoring, branded entertainment, or product integration--is a marketing practice in advertising and promotion wherein a brand name, product, package, signage, or other trademark merchandise is inserted into and used contextually in a motion picture, television, or other media vehicle for commercial purposes. In product placement, the involved audience gets exposed to the brands and products during the natural process of the movie, television program, or content vehicle.

- What they touch-The touch is the only sense which gives a physical belonging to the brand. The brand essence should be seen through the packaging of the brand. The appeal for kids needs to be packaged in a manner to make it look gentler and give a feeling of being pampered.

\section{Conclusions}

Sensory branding is not a breakthrough concept when the brand is at Infancy level more than two senses of branding is required. To present a holistic brand to its audiences, a strategic experience is required to promote both the online and offline brand experience. For olfactory branding, Sensory branding, audio branding, a Sensory Specialist is what is required to be hired. A broad set skill is required to create brand stewardship and it's not as simple as it appears.

For the brand, an exhaustive and fool proof sensory profile needs to be created. To identify the most pertinent ones, it's important to develop an inventory of sensory impression of the brand. To develop meaningful associations, a series of questions can help. Some questions to mentioned can be how strongly a particular intelligence comes to brain for the brand? How is the alliance-optimistic or pessimistic? Is the association really distinctive? Is the association meaningful? Does the association evoke memories and emotions? An investigation and successful answering of the above questions can make a brand successful and touch the customer at 360 degree and forges and irreversible associations.

A brand cannot spread its aroma through television sets and newspapers, but there is nothing stopping the aroma from being entirely incorporated in the brand. To create an impactful brand the idea is to engage the customers on all variety of touch points.

\section{References}

[1] Lindstrom, M. (3005) Brand Sense: How to Build Powerful Brands through Touch, Taste, Smell, Sight and Sound. Kogan Page Limited.

[2] Ghodeswar, B.M. (3008) Building Brand Identity in Competitive Markets: A Conceptual Model. Journal of Product \& Brand Management, 17, 4-12. https://doi.org/10.1108/10610420810856468

[3] Djurovic, V. (3008) Sensorial Branding-The Future of Brands Building. http://ezinearticles.com/?Sensorial-Branding-The-Future-of-Brand-Building\&id= 1413143

[4] Lindstrom, M. (3005) Broad Sensory Branding. Journal of Product \& Brand Man- 
agement, 14, 84-87. https://doi.org/10.1108/10610420510592554

[5] Keller (3003) Strategic Brand Management: Building, Measuring, and Managing Brand Equity. Prentice Hall, Upper Saddle River.

[6] Krishna, A. and Elder, R. (3010) The Gist of Gustation, Sensory Marketing. Psychology Press, London.

[7] Upshaw, L.B. (1995) Building Brand Identity. John Wiley \& Sons, Inc., New York.

[8] Winter, A. and Winter, R. (3003) Brain Workout: Easy Ways to Power up Your Memory, Sensory Perception, and Intelligence. Asia Press, New Jersey.

[9] Vlahos (3007) Scent and Sensibility: Can Smell Sell? New York Times, 69-73.

Submit or recommend next manuscript to SCIRP and we will provide best service for you:

Accepting pre-submission inquiries through Email, Facebook, LinkedIn, Twitter, etc. A wide selection of journals (inclusive of 9 subjects, more than 200 journals)

Providing 24-hour high-quality service

User-friendly online submission system

Fair and swift peer-review system

Efficient typesetting and proofreading procedure

Display of the result of downloads and visits, as well as the number of cited articles

Maximum dissemination of your research work

Submit your manuscript at: http://papersubmission.scirp.org/

Or contact ajibm@scirp.org 